\title{
Tiimit opettajien perinteisten työkäytäntöjen murtajina
}

\author{
Merja Kärkkäinen
}

\author{
Koulut ovat murrosvaiheessa ja opettajien työtapa on \\ muuttumassa yksilöllisestä luokkahuonetyöskentelystä \\ tiimimäisemmäksi ja verkostomaisemmaksi työtavaksi. \\ Tiimipuheen laatu on merkittävää tiimityön ja \\ opetuksen suunnittelun onnistumisen kannalta. Tiimin \\ kehitys ei ole kuitenkaan lineaarista ja mitattavissa vain \\ yhdellä ulottuvuudella. Tiimin toiminta saattaa \\ samanaikaisesti sekä kehittyä että taantua sen \\ toimintajärjestelmän eri elementtien osalta.
}

Väitöskirjatutkimukseni on osa akatemiaprofessori Yrjö Engeströmin johtamaa, useita eri toimialoja, mm. teollisuutta, terveyskeskuksia ja oppilaitoksia tutkivaa projektia "Muutoksen hallinta oppivissa tiimi- ja verkostotyyppisissä organisaatioissa“. Oma väitöskirjatutkimukseni käsittelee opettajatiimissä tapahtuvan opetuksen suunnittelun onnistumisen edellytyksiä ja esteitä. Väitöskirjani on ensisijaisesti empiirinen ja metodologinen tutkimus.

$\mathrm{P}$ eruskoulun opettajien tiimityön edellytyksiä ja esteitä ei ole juuri tutkittu. Miksi opettajien tiimityötä kannattaa sitten tutkia? Miksi tiimi- ja verkostoperustainen työtapa olisi menestyksekkäämpi kuin perinteinen yksilöopettajien luokkahuonekeskeinen työtapa? Tiimityön arviointi edellyttää empiiristä tietoa ja teoreettista ymmärrystä ilmiöstä. Sovellan tutkimuksessani kulttuurihistoriallista toiminnan teoriaa ja kehittävää työntutkimusta. Tutkin koulua opettajien työpaikkana. Koulu- ja opettajatutkimuksessa sijoitan tutkimuskohteeni koulureformien, paikallisen opetussuunnitelmatyön ja opettajien yhteistoiminnan tutkimuskenttiin.

Koulut ovat murrosvaiheessa ja alttiita erilaisille muutospaineille. Mm. internetin ansiosta tiedon sisällöt muuttuvat nopeasti. Oppilaiden pitäisi oppia uusia toimintavalmiuksia, mm. informaation käsittelyä ja oppimisen tulosten tulisi parantua. Koulujemme, samoin kuin monien muiden organisaatioiden tehottomuutta arvostellaan. Koulut ovat vastuussa omasta pärjäämisestään mikä merkitsee, että koulujen erot kasvavat koulujen kilpaillessa keskenään. Toisaalta työelämän sisäiset rakenteet ovat uudistumassa. Tänä päivänä, näin 2000-luvun kynnyksellä, tietoverkkojen 
leviäminen ja teknologian kiihtyvä kehitys korostavat kansainvälistymistä ja globalisaatiota työelämässä. Uusi teknologia muuttaa lähes kaikkia työtehtäviä. Tiedon lisääntyminen ei kuitenkaan aina edistä asioiden ja ilmiöiden hallittavuutta, vaan se saattaa johtaa kasvavaan epävarmuuteen. Työelämä vaatii monitaitoisuutta ja muutoksen hallinnan taitoja. Muutoksen toteuttaminen tulisi olla luonnollinen osa opettajien työtä - koulu ei voi välttyä muutoksilta.

Tiimityöstä on tullut käytännön työmuoto yhä useammissa organisaatioissa. Myös koulun toiminnan kehittämiseksi monissa peruskouluissa on perustettu opettajatiimejä. Tutkimustani motivoiva kysymys on ollut se, millä tavoin opettajien tiimityö murtaa perinteistä, luokkahuonekeskeistä opetusta. Tiimityö sinänsä ei ole koulussa uusi asia. TEAM TEACHING -käsite sai alkunsa USA:ssa 1960-luvulla (Beggs, 1964). Kuitenkaan tiimityötä ei ole tarkasteltu siinä mielessä, että se muuttaisi opettajien ja koulun henkilökunnan työtä.

Monissa tutkimuksissa on tullut ilmi, että koulu ja opettajien työ ovat vaikeasti muutettavissa (Sarason, 1990). Tutkijat ovat raportoineet, että esimerkiksi oppilaskeskeisiä työmuotoja suosinut reformipedagogiikka ei ole useinkaan onnistunut muuttamaan perinteisen luokkahuonetyöskentelyn mallia (Cuban, 1984). Viime vuosikymmeninä Suomessa opetussuunnitelmat ovat toimineet keskitetyn ohjauksen ja valvonnan välineenä. 90-luvulla on purettu opetussuunnitelmien keskitettyä ohjausta ja valvontaa ja vastuuta opetussuunnittelusta on siirretty kunnille ja kouluille. Oma tutkimukseni sijoittuu aikaan, jolloin tutkimukseni kohteena oleva koulu otti ensiaskeleitaan koulukohtaisen opetussuunnitelmansa suunnittelussa opettajien ja rehtorin yhteistyönä.

Tiimityön onnistumisen esteistä ja edellytyksistä on kirjoitettu paljon. Tiimin kehitys esitetään kirjallisuudessa usein tapahtuvaksi tiettyjen vaiheiden kautta työryhmästä huipputiimiksi (Katzenbach ym., 1993). On tuotu esiin myös, että tiimityö sinänsä ei riitä, vaan tiimin on opittava rikkomaan rajojaan ja verkostoitumaan (An-

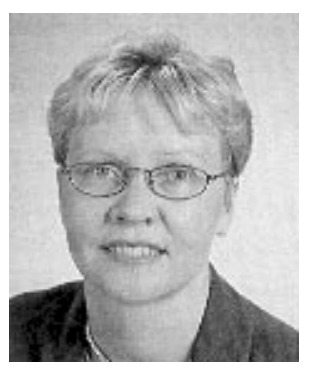

Merja Kärkkäinen

cona ym., 1992). Peruskoulussa tämä tarkoittaa, että opettajatiimien olisi opittava käyttämään omiaan, koulun, oppilaiden ja heidän vanhempiensa verkostoyhteyksiä sekä tietoverkkoja hyödyksi oppilaiden oppimisen edistämiseksi (mm. Moll \& Greenberg, 1990).

Viime aikoina tutkijat ovat alkaneet kiinnittää huomiota tiimipuheeseen (esimerkiksi Donnellon, 1996). Tiimikeskustelun luonne voi joko edistää tai ehkäistä ongelmanratkaisua ja oppimista tiimissä. Opettajien tiimipuheeseen kuitenkin on tähän mennessä kiinnitetty vain vähän huomiota opettajatutkimuksessa (Kärkkäinen, 1996). Omassa tutkimuksessani olen nostanut tiimikeskustelun luonteen näkyviin tiimityön esteitä ja edellytyksiä tarkastellessani.

$\mathrm{T}$ utkimukseni on pitkittäistutkimus. Tutkin ala-asteen koulussa kahta eri opettajatiimiä perättäisinä vuosina (1993-1994). Opettajien tiimityön kehittyminen tutkittujen kahden vuoden aikana ei ollut jatkuvaa, sillä koulussa tapahtui opettajien yhteistyön organisointimuutos. Ensimmäisenä vuonna tutkimuksen kohteena oleva tiimi oli opettajien omasta aloitteesta perustettu erillinen viiden opettajan tiimi. Tiimi suunnitteli ja toteutti oman tiimityöskentelyn mallinsa sekä kaksi kuukautta käsittävän kotiseutu -teemakokonaisuuden. Kutsun tätä tiimiä teematyöskentelytiimiksi. Toisena tutkimuksen vuonna koko koulu oli organisoitu hallinnollisesti kolmeen opettajatiimiin. Tiimien tehtäväksi oli annettu suunnitella ja toteuttaa valinnaiskursseja. Tutkin tuolloin kahdeksan hengen valinnaiskurssitiimiä. Jatkuvuutta edusti kolme mu- 
UU T T A T U T K I M U K S E S T A

Taulukko 1: Tutkimusongelmat, käytetty aineisto, keskeiset metodiset oivallukset ja sisällölliset tulokset

\begin{tabular}{|c|c|c|c|}
\hline $\begin{array}{l}\text { TUTKIMUS- } \\
\text { ONGELMAT }\end{array}$ & AINEISTO & METODOLOGINEN TULOS & SISÄLLÖLLINENTULOS \\
\hline $\begin{array}{l}\text { 1) Millaisia yhtä- } \\
\text { läisyyksiä ja eroja } \\
\text { on suomalaisten } \\
\text { ja amerikkalaisen } \\
\text { opettajatiimien } \\
\text { opetuskokonai- } \\
\text { suuksien laadin- } \\
\text { nassa? (luku 6) }\end{array}$ & $\begin{array}{l}\text { Kuvanau- } \\
\text { hoitetut } \\
\text { kokoukset, } \\
\text { haastattelut, } \\
\text { etnografinen } \\
\text { aineisto }\end{array}$ & $\begin{array}{l}\text { Suomalaisten ja amerikka- } \\
\text { laisen tiimien erilaisten } \\
\text { suunnittelun kaarten } \\
\text { operationalisointi (pu- } \\
\text { heen rakenneominaisuu- } \\
\text { det, puheen sisältö) }\end{array}$ & $\begin{array}{l}\text { Suunnittelukaarten erojen } \\
\text { selittäminen toimintajär- } \\
\text { jestelmän käsitteen avulla. } \\
\text { Tiimit eivät kehittyneet } \\
\text { lineaarisesti vaan samalla } \\
\text { jokin toimintajärjestelmän } \\
\text { elementti kehittyi ja jo- } \\
\text { kin toinen taantui. }\end{array}$ \\
\hline $\begin{array}{l}\text { 2) Millä tavoin } \\
\text { suomalaisten } \\
\text { opettajatiimien } \\
\text { suunnittelukes- } \\
\text { kustelun sisällöt } \\
\text { erosivat toisistaan } \\
\text { ennen ja jälkeen } \\
\text { opettajien yhteis- } \\
\text { työn organisoin- } \\
\text { nin muutoksen? }\end{array}$ & $\begin{array}{l}\text { Kuvanau- } \\
\text { hoitetut } \\
\text { kokoukset }\end{array}$ & $\begin{array}{l}\text { Sosiaalisten kielten opera- } \\
\text { tionalisointi opettajatii- } \\
\text { mien puheessa tutkimalla } \\
\text { opettajien työn teoriahis- } \\
\text { toriallisia juuria ja opetta- } \\
\text { jien tiimikokouskeskuste- } \\
\text { luja }\end{array}$ & $\begin{array}{l}\text { Opettajatiimin puhe } \\
\text { heijasteli opettajien } \\
\text { yhteistyön uudelleenor- } \\
\text { ganisointia siten, että } \\
\text { puhe muuttui pedagogi- } \\
\text { sesti orientoituneesta } \\
\text { alhaaltapäin perustetun } \\
\text { tiimin puheesta koko } \\
\text { koulua käsittäväksi, hal- } \\
\text { linnolliseksi valinnais- } \\
\text { kurssien koordinointi- } \\
\text { puheeksi. }\end{array}$ \\
\hline $\begin{array}{l}\text { 3) Millä tavoin } \\
\text { opettajatiimien } \\
\text { yhteistyöhön } \\
\text { perustuvaa op- } \\
\text { pimista voi käsit- } \\
\text { teellistää ja tun- } \\
\text { nistaa? (luku 8) }\end{array}$ & $\begin{array}{l}\text { Kuvanauhoi- } \\
\text { tetut } \\
\text { kokoukset }\end{array}$ & $\begin{array}{l}\text { Kohteenmuodostuksen } \\
\text { käännekohtien operatio- } \\
\text { nalisointi, } \\
\text { häiriöryväkset ja oppimi- } \\
\text { sen tuloksen tunnistami- } \\
\text { nen käännekohdan aikana }\end{array}$ & $\begin{array}{l}\text { Tiimi 1: Suunnittelun } \\
\text { kohde kaksitasoinen: } \\
\text { "teematyöskentely" - } \\
\text { käsitteen luonti ja koti- } \\
\text { seututeeman suunnit- } \\
\text { telu. } \\
\text { Tiimi 2: Suunnittelun } \\
\text { kohde yksitasoinen: } \\
\text { erillisten kurssien suun- } \\
\text { nittelu }\end{array}$ \\
\hline $\begin{array}{l}\text { 4) Millä edelly- } \\
\text { tyksin tiimit } \\
\text { luovat verkosto- } \\
\text { suhteita? } \\
(\text { luku 9) }\end{array}$ & $\begin{array}{l}\text { Kuvanauhoi- } \\
\text { tetut } \\
\text { kokoukset, } \\
\text { haastattelut, } \\
\text { havainnoin- } \\
\text { tiaiaineisto }\end{array}$ & $\begin{array}{l}\text { Verkostosuhteiden ope- } \\
\text { rationalisointi kolmen- } \\
\text { tyyppisen aineiston kaut- } \\
\text { ta (triangulaatio) koh- } \\
\text { teellisina verkostosuhtei- } \\
\text { na }\end{array}$ & $\begin{array}{l}\text { Yhdeksän eri koordi- } \\
\text { natiivisen tai kooperatii- } \\
\text { visen verkostosuhteen } \\
\text { tunnistaminen. Tiimin } \\
\text { verkostosuhteiden muo- } \\
\text { dostaminen edellytti } \\
\text { tiimiltä yhteisen koh- } \\
\text { teen rakentamista } \\
\text { kooperaatiossa. Solmu- } \\
\text { työskentely -tyyppisen } \\
\text { työtavan tunnistaminen } \\
\text { valinnaiskurssitiimissä. }\end{array}$ \\
\hline
\end{tabular}


kana ollutta jäsentä edellisen vuoden tiimistä. Kutsun tätä tiimiä valinnaiskurssitiimiksi. Tiimi suunnitteli ja toteutti kaksi kuukautta kestäviä erillisiä valinnaiskursseja. Valinnaiskurssitiimeihin osallistuminen ei ollut opettajille pakollista. Erillisessä koulurakennuksessa toimi valinnaiskurssitiimien rinnalla myös ns. epävirallinen tiimi, joka kokoontui silloin tällöin valinnaiskurssien toteutuksen aikana, vaikka kaikki jäsenet eivät ottaneet osaa kyseiseen valinnaiskurssijaksoon.

Vertaan tutkimustuloksiani suomalaisten opettajatiimien toiminnasta laajemmassa tutkimusprojektissa mukana olleen amerikkalaisen opettajatiimin tuloksiin jo kirjoitetun Claire Buchwaldin (1995) väitöskirjan perusteella. Kontrastointi ja vertaaminen on tärkeätä, jotta suomalaisten opettajatiimien toiminta suhteutuu muihin kulttuureihin ja ymmärrys niiden omasta erityisluonteesta lisääntyy.

Tutkimukseni aineisto on kolmentyyppistä käsittäen opettajien ja rehtorin haastattelut suunnitteluprosessien alussa ja lopussa, kuvanauhoitetut tiimikokoukset suunnitteluprosessien aikana sekä videonauhoitetun havainnointi- eli varjostamisaineiston (Sachs, 1993) opetuksen toteuttamisen aikana. Tutkimukseni tulososa koostuu neljästä eri empirialuvusta. Jokainen luku tuottaa uusia metodologisia ratkaisuja siitä, kuinka analysoida tiimipuhetta- ja tiimityötä. Luvut tuottavat myös kiinnostavia sisällöllisiä tuloksia ja käsitteellisiä sekä konkreettisia välineitä koululle, opettajille ja ylipäätään työtiimeille kehittää toiminta- ja vuorovaikutuskäytäntöjään. Kulttuurihistoriallisen toiminnan teorian näkökulmasta etenen yleisemmistä tutkimuskysymyksistä yhä syvemmälle meneviin tutkimuskysymyksiin.

$\mathrm{E}$ nsimmäinen tutkimuskysymykseni oli: "Mitkä ovat yhtäläisyydet ja erot suomalaisten ja amerikkalaisen opettajatiimien opetuskokonaisuuksien laadinnassa?" (taulukko 1). Molemmissa maissa opettajatiimit suunnittelivat kahtena eri vuonna noin kaksi kuukautta kestäviä opetuskokonaisuuksia. Tiimit perustettiin ensimmäisenä tutkittuna vuonna opettajien omasta aloitteesta molemmissa maissa. Suomessa tiimityön organisoinnin muutos tapahtui siis toisena vuonna, mutta amerikkalainen tiimi jatkoi toimintaansa. Luvun keskeinen metodologinen tulos on kahden eri kulttuurin tiimien erilaisten suunnittelun kaarten operationalisointi ja tunnistaminen keskustelun vuoronvaihtojen, keskustelussa esiintyvien modusten ja keskustelun puheenaiheiden sekä huolenaiheiden tunnistamisen avulla.

Luvun keskeinen sisällöllinen tulos on suunnittelukaarten erojen selittäminen toimintajärjestelmän käsitteen avulla. Analysoin tuloksia myös sukupuoli- ja kulttuurierojen valossa, mutta niiden avulla en saanut eroa yksiselitteisesti selitetyksi. Toimintajärjestelmän käsite mahdollisti tiimien systeemisten ja kontekstuaalisten tekijöiden kuvaamisen suunnittelukaarten eroja selitettäessä. Amerikkalainen tiimi suunnitteli molempina vuosina kaikille jäsenilleen yhteistä opetuskokonaisuutta. Suomalaisen tiimin vuorovaikutuksen luonne muuttui ja suunnittelun kohde pirstaloitui erillisten kurssien suunnitteluksi. Analysoin luvussa kuinka tiimin kehitys tulisi ymmärtää. Mikä on taantumista ja mikä taas kehittymistä? Tulokset osoittivat, että tiimit eivät kehittyneet lineaarisesti vaan jokin toimintajärjestelmän elementti kehittyi ja ekspansoitui aiemmin ja jokin toinen samaan aikaan taantui. Suomalaisessa tiimikehityksessä mm. työyhteisö ekspansoitui käsittäen koko opettajakunnan, mutta suunnittelun kohde pirstaloitui erillisiksi yksilöopettajien suunnittelemiksi kursseiksi. Amerikkalaisessa tiimi otti mukaansa tilapäisesti ongelmanratkaisunsa kannalta oleellisia lisäjäseniä ja näinollen sekä kohde että yhteisö ekspansoituivat. Tiimien kehitys ei tapahtunut kummassakaan maassa ainoastaan tiimin sisällä vaan oleellista oli tiimin rajojen rikkoutuminen ja tiimien suuntautuminen ulospäin.

$\mathrm{T}$ oisena tutkimusongelmanani oli: "Millä tavoin suomalaisten opettajatiimien suunnittelukeskustelun sisällöt erosivat toisistaan ennen ja jälkeen kun opettajien tiimityö organisoitiin koulussa uudestaan?" (taulukko 1). Tutkimuskysymyksen käsittely tuo tutkimukseeni koulun ja opettajien työn teoriahistoriallisen perspektiivin. Tarkastelen opettajien tiimipuhetta ope- 
tustyön välineenä opettajien yhteistyön muutosta työstettäessä. Käyttämäni sosiaalisen kielen käsite on peräisin Bakhtinin teoriasta (1982, 1987). Puheessamme on erotettavissa se kulttuurihistoriallinen sosiaalinen kieli tai ne kielet, joita käytämme puhumisemme resurssina. Luvun tärkein metodinen oivallus on sosiaalisen kielen operationalisointi. Operationalisoin opettajatiimin puheessa esiintyvät sosiaaliset kielet erittelemällä toisaalta opettajien työn teoriahistoriallisia juuria ja toisaalta tutkimalla samaan aikaan opettajien suunnittelukokouskeskusteluja - transkripteja. Nimesin opettajatiimissä esiintyvät kielet ja jaottelin ne tarkemmin erilaisiin variaatioihin pääkielten sisällä. Kaikkea puhetta ei ollut mahdollista jaotella näihin tunnistettavissa oleviin kielten variaatioihin. Tämä puhe tarkasteltiin erikseen uutena, ns. syntymässä olevana sosiaalisena kielenä.

Sosiaalisten kielten analyysi tuotti kiinnostavia sisällöllisiä tuloksia. Löysin opettajatiimien keskustelusta kolme pääkieltä: 1) käytännön kokemuskielen, 2) hallinnollisen kielen ja 3) pedagogisten uudistusten kielen sekä tarkemmat variaatiot näiden alla. Tunnistin kehkeytymässä olevia uusien sosiaalisten kielten ituja, jotka ilmenivät tietynlaisena kritiikki- ja itsekritiikkipuheena vallitsevaa pedagogista käytäntöä kohtaan. Opettajatiimin puhe reflektoi opettajien yhteistyön uudelleenorganisointia siten, että puhe muuttui pedagogisesti orientoituneesta alhaaltapäin perustetun tiimin puheesta koko koulua käsittävään, hallinnolliseen valinnaiskurssien koordinointipuheeseen.

$\mathrm{K}$ olmas tutkimuskysymykseni kuului: "Millä tavoin opettajatiimien yhteistyöhön perustuvaa oppimista voidaan käsitteellistää ja tunnistaa?" (taulukko 1). Analysoin opettajien tiimikeskustelujen avulla suunnitteluprosessia yhteistoiminnallisena oppimisponnistuksena. Oppimisen ymmärrän tässä ennen kaikkea tiimin yhteistyönä tapahtuvan yhteisen toiminnan kohteen kehittymisenä. Toiminnan teoriassa toiminta määritellään toiminnan kohteen kautta (Leontjev, 1978). Kehitin metodologisen tavan analysoida ja käsitteellistää yhteistoiminnallista oppi- mista tiimin kohteenmuodostuksen käännekohtien avulla.

Käännekohta tarkoittaa sellaista tilannetta opettajatiimin suunnittelukeskustelussa, jolloin keskustelun kohde ja suunnittelun sisällöt alkoivat muodostua uudella tavalla. Käännekohdat operationalisoin kolmen käsitteen eli häiriöryväksen (Engeström ym., 1991), kyseenalaistuksen ja äänen (Bakhtin, 1982) käsitteen avulla. Erotin käännekohdista myös oppimisen tuloksen. Sisällöllinen kohde joko laajentui, kaventui tai hajosi.

Keskeisenä sisällöllisenä tuloksena käännekohtaanalyysi tarkensi tutkimieni tiimien suunnittelun kohteiden erilaisuutta. Teematyöskentelytiimin suunnittelun kohde ilmeni kahdella tasolla. Ensinnäkin tiimi kehitti suunnitteluprosessin alussa työskentelymallilleen käsitteen "teematyöskentely“. Toiseksi tiimi suunnitteli, toteutti ja arvioi konkreettisen teemakokonaisuuden, kotiseututeeman. Valinnaiskurssitiimin kohde oli yksitasoinen. Tiimi otti valinnaiskurssien käsitteen annettuna, ja suunnitteli ja toteutti erilaisia valinnaiskursseja vailla yhteistä suunnittelun kohdetta. Teematyöskentelytiimin malliin kuuluneen yhteisen teeman ajatusta ei kuitenkaan haudattu tiimissä, vaan jännitteen "yhteinen teema vs. pirstaleiset kurssit" työstäminen tiimipuheessa johti siihen, että opettajat päättivät sitoa seuraavan valinnaiskurssijakson yhteiseen teemaan.

$\mathrm{T}$ utkimusongelmassa (4), “Millä edellytyksin tiimit luovat verkostosuhteita?" (taulukko 1) tarkastelen tiimien ulkoista perspektiiviä opettajatiimin verkostosuhteita. Opettajat rakensivat yhdessä verkostoja tiiminä, eli kyse oli tiimiverkosta (ks. Lipnack \& Stamps, 1993). Kehitin metodin, jonka avulla analysoin ja kuvasin opettajatiimien ja oppilaiden opetuksen suunnitteluun ja toteutukseen liittyviä verkostosuhteita. Tarkastelin verkostokontaktien rakentamista toiminnan teorian mukaisesti kohteellisen toiminnan (vrt. Miettinen, 1998) näkökulmasta. Verkostosuhteiden kohteellisuutta tutkiessani käytin käsitteitä koordinaatio ja kooperaatio (vrt. Engeström ym., 1991) KOOPERAATIO tarkoitti, että 
opettajat suunnittelivat ja työstivät yhteistä kohdetta, teemakokonaisuutta. KoORDINAATIO puolestaan tarkoitti, että toimijat koordinoivat, mutta eivät työstäneet yhteistä sisällöllistä kohdetta.

Tutkin verkostoja kaikkien keräämieni kolmentyyppisen aineiston kautta. Metodologisesti oli oleellista kuvata tiimien verkostoyhteyksiä monen aineiston kautta triangulaationa (ks. Guba \& Lincoln, 1985) edistäen tutkimuksen validiteettia ja reliabiliteettia. Yksinään kaikilla aineistotyypeillä olisi ollut tiettyjä heikkouksia kuvata opettajatiimin verkostojen kirjoa.

Tutkimuksen sisällöllisenä tuloksena tunnistin yhdeksän erilaista koordinatiivista tai kooperatiivista verkostosuhdetta. Nämä verkostosuhdekategoriat oli hyödyllistä nähdä tiimin opetustyön välineinä toiminnan laajentamisessa luokan ulkopuolelle. Kannattaa huomata, että tiimin jäsenten usein satunnaiset verkostokontaktit ovat erittäin kustannustehokkaita tiimin ongelmanratkaisun välineitä (vrt. Granovetter, 1973, Krackhard, 1990). Tulokset osoittivat, että verkostosuhteiden muodostaminen edellytti tiimiltä yhteisen kohteen kooperatiivista rakentamista. Teematyöskentelytiimin osalta perinteinen koulutyö murtui siinä mielessä, että opettajatiimi käytti erittäin paljon verkostosuhteita opetuskokonaisuuden aikana ja samalla oppilaiden oppimisen konteksti laajeni. Toisaalta on huomattava, että tämä ekspansio jäi yhden tiimin saavutukseksi eikä levinnyt tehokkaasti muuhun kouluyhteisöön.

Valinnaiskurssitiimin verkostosuhteet olivat suppeat, vaikka yhteisö laajeni koko koulun käsittäväksi opettajakunnaksi. Jokainen opettaja suunnitteli kurssisisältönsä yksin. Toisaalta on huomattava, että yhteisö laajentui huomattavasti koko koulun opettajakunnan osallistuessa tiimityöhön. Tiimityöskentely tuli tutuksi koko koulussa eikä jäänyt vain yhden tiimin asiaksi. Kiinnostavaksi havainnoksi muodostui solmutyöskentely-tyyppisen työtavan tunnistaminen valinnaiskurssitiimissä havainnointiaineiston avulla. Yrjö Engeströmin (1999) kehittämä solmutyöskentely käsite tarkoittaa yhteistoimintaa, jossa "solmu" asian kanssa tekemisissä olevia ihmisiä kokoontuu rat- kaisemaan jonkin akuutin ongelman tai asian mahdollisimman nopeasti. Puheeni alussa mainitsema epävirallinen tiimi erillisessä koulurakennuksessa työskenteli lähellä toisiaan ja joustavasti ratkoi keskenään ongelmia valinnaiskurssien toteutuksen aikana. Tämän solmutyöskentelytyyppisen työtavan voi tulkita iduksi uudenlaisesta nousemassa olevasta yhteistyön muodosta. Se muistutti teematyöskentelytyötapaa, mutta erosi siitä joustavuutensa ja epävirallisuutensa vuoksi. Kun tiimi oli ratkaissut ongelman, solmua ei enää tarvittu. Opettajasolmu solmiutui taas uudelleen seuraavan ongelman ilmetessä.

Tutkimukseni problematisoi kysymyksen tiimin kehityksen luonteesta; mikä on kehittymistä tai taantumista. Törmäsin tähän kysymykseen jo kerätessäni aineistoa valinnaiskurssitiimistä, sillä ne kolme opettajaa, jotka osallistuivat molempien vuosien tiimityöhön itse kokivat valinnaiskurssitiimien toimivan paremmin kuin teematyöskentelyä soveltavan tiimin, vaikka asia näytti tutkijasta päinvastaiselta. Tämä paradoksi suuntasi kiinnostukseni tarkastelemaan tiimin kehityksen luonnetta. Tulokset osoittivat, että tiimin kehittyminen ei ole yksiselitteinen kysymys. Tiimien toiminta saattaa samanaikaisesti kehittyä ja taantua toimintajärjestelmän eri elementtien osalta. Tiimin suunnittelun sisältö oli riippuvaista tiimin kohteen muodostuksesta. Teematyöskentelytiimin suunnittelun kohde oli yhteisesti jaettu Kotiseututeema. Valinnaiskurssitiimissä kurssikokonaisuutta koordinoitiin, mutta jokainen opettaja suunnitteli oman kurssinsa yksin. Tiimin puhe muuttui pedagogisesta suunnittelupuheesta valinnaiskurssien koordinointipuheeksi. Ratkaisevaksi kysymykseksi muodostuikin, pystyykö valinnaiskurssitiimi suunnittelemaan ja muodostamaan yhteistä kohdetta. Ituja ainakin tähän suuntaan oli havaittavissa, sillä tiimi päätti soveltaa yhteisen teeman ideaa seuraavassa valinnaiskurssijaksossa. Opittiinko sitten koulussa jotain tutkittujen tiimien kokemuksista? Seurasin vuoden 1998 kevääseen koulun toimintaa haastatteluin. Haastattelujen perusteella tiimityö on ollut tutkimassani koulussa jatkuvan kehityksen alaisena. Opettajatiimit toteuttivat sekä erillisiä valinnaiskursseja että yhteisen teeman ympärille muodostuvia valinnaiskursseja. 
Tämän lisäksi kouluun oli perustettu pysyviä tiimejä fyysisen läheisyyden periaatteen mukaan sekä erilaisia projektiluontoisia kehitystiimejä. Myös solmutyöskentelytyyppinen työtapa oli käytössä akuuttien ongelmien ratkaisua varten.

Tutkimukseni tulosten perusteella tiimin kehitys ei siis ole lineaarista ja mitattavissa vain yhdellä ulottuvuudella kuten perinteinen tiimikirjallisuus on antanut olettaa (ks. Katzenbach ym., 1993). Työelämän kehittäjän, tutkijan ja konsultin olisi hyvä pitää tämä asia mielessään omassa kehittämistyössään, tuskin työn kehittämiseksi tarkoitetut interventiotkaan toimivat siten, kuin kehittäjä on alun perin ne suunnitellut. Paremmaksi tuleminen ja kehittyminen on rosoisempi ilmiö.

Tutkimukseni nostaa esiin joitain jatkotutkimusaiheita. Kun keskustellaan siitä, mikä on menestyksellistä opetustyötä, ei voida ohittaa kysymystä oppilaiden oppimisen laadusta. Opetus- ja oppimisprosessit kietoutuvat elimellisesti toisiinsa. Jatkossa tutkimuksen painopistettä voi siirtää oppimisen tuloksellisuuden tarkasteluun yhdistettynä koulun ja opettajien työn muutokseen.

\section{Lähteet}

ANCONA, D. G. \& Caldwell, D. (1992). Demography and Design: Predictors of New Product Team Performance. Organization Science, 3 (3), p. 321 341 .

BAKHTIN, M. M. (1982). The Dialogic Imagination. Four Essays. Austin: University of Texas Press.

BAKHTIN, M. M. (1987). Speech Genres and Other Late Essays. Austin: University of Texas Press.

BEGGS, D. W. (1964). Team Teaching: Bold New Venture. Indianapolis: Unified College Press

BUCHWALD, C. (1995). New Work in Old Institutions: Collaborative Curriculum Work of a Teacher Team. Unpublished dissertation. San Diego: Department of Communication, University of California, San Diego

CUBAN, L. (1984). How Teachers Taught, Constancy and Change in American Classrooms 1890-1980. New York: Longman.

DONNELlON, A. (1996). Team Talk. The Power of Language in Team Dynamics. Boston: Harvard Business School Press

ENGESTRÖM, Y. (1987). Learning by Expanding: An Activity-theoretical Approach to Developmental Research. Helsinki: Orienta-Konsultit.

ENGESTRÖM, Y., Brown, C., Christopher, L.C., \& Gre- gory, J. (1991). Coordination, Cooperation and Communication in the Courts: Expansive Transitions in Legal Work. The Quarterly Newsletter of the Laboratory of Comparative Human Cognition, 13 (4), p. 88-97.

ENGESTRÖM, Y., Engeström, R., \& Vähäaho, T. (1999). When the Center Doesn't Hold: The Importance of Knotworking. In M. Hedegaard, S. Chaiklin \& U. J. Jensen (Eds.), Proceeding book of the Fourth Congress of the International Society for Cultural Research and Activity Theory. Aahus: Aarhus University Press.

GUBA, E. G. \& Lincoln, Y. S. (1985). Naturalistic Inquiry. Beverly Hills: Sage.

KATZENBACH, J.R. \&Smith, D.K. (1993). The Wisdom of Teams: Creating the High-performance Organization. Boston: Harvard Business School Press.

KRACKHARDT, D. (1990). Assessing the Political Landscape. Structure, Cognition and Power in Organizations. Administratively Science Quarterly, 35, p. 342-369

KÄRKKÄINEN, M. (1996). Comparative Analysis of Planning Trajectories in Finnish and American Teacher Teams. Nordisk Pedagogik 16 (3), p. 167 190.

LEHTINEN, E. (1984). Motivating Students towards Planning and Controlling of Thinking Activities. A Constructivistic Approach to Learning. Turku: the University of Turku

LEONTJEV, A. N. (1977). Activity, Consciousness, and Personality. Englewood Cliffs: Prentice-Hall

LIPNACK, J. \& Stamps, J. (1993). The Teamnet Factor. Bringing the Power of Boundary Crossing into the Hearth of Your Business. Essex Junction: Oliver Wright Publications, Inc.

MIETTINEN, R. (1998). Object Construction and Networks in Research Work: The Case of Research on Cellulose Degreasing Enzymes. Social Studies of Science, Vol. 28 (3), p. 423-463.

MOLL, L.C. \& Greenberg, J.B. (1990). Creating Zone of Possibilities: Combining Social Context for Instruction. In L.C. Moll (Ed.), Vygotsky and Education: Instructional Implications and Applications of Sociohistorical Psychology, p 319-348. Cambridge: Cambridge University Press

SACHS, P. (1993). Shadows in the Soup: Conceptions of Work and Nature of Evidence. The Quarterly Newsletter of the Laboratory of Comparative $\mathrm{Hu}$ man Cognition, 15 (4), p. 125-132.

SARASON, S. B. (1990). The Predictable Failure of Educational Reform. San Francisco: Jossey-Bass

Lectio praecursoria. Merja Kärkkäinen puolusti väitöskirjaansa "Teams as breakers of traditional work practices - A longitudinal study of planning and implementing curriculum units in elementary school teacher teams" Helsingin yliopiston kasvatustieteellisessä tiedekunnassa 20.8.1999 vastaväittäjänä tohtori Terttu Tuomi-Gröhn. 